\title{
Lithic raw material economy at the Huayang site in Northeast China: localization and diversification as adaptive strategies in the Late Glacial
}

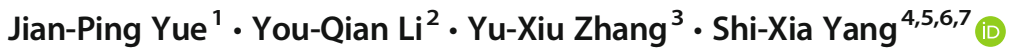 \\ Received: 16 February 2020 / Accepted: 14 April 2020 / Published online: 8 May 2020 \\ (C) The Author(s) 2020
}

\begin{abstract}
The study of lithic raw material plays an important role in developing archeologists' understanding of the different adaptive strategies and behaviors of prehistoric people. In this paper, we present new evidence from the Huayang site that reveals lithic raw material procurement and exploitation strategies dating to around $14 \mathrm{ka}$ cal. BP. The Huayang site is located in the southern portion of the Lesser Khingan Mountains in Northeast China, a key region for examining migration, diffusion, and interaction among hunter-gatherers in East and Northeast Asia. Our results indicate that diversified lithic raw materials were found and procured from local riverbeds and reduced at the site. Each raw material was reduced with distinctive knapping strategies and, as a result, there is a strong discrete spatial pattern for each of the different raw material types. Intra- and inter-site comparative analyses suggest a uniform trend towards localization and diversification of lithic raw materials in the southern Lesser Khingan Mountains, Northeast China during the Late Glacial, which seems to be associated with the paleoclimatic amelioration and the demographic expansion during this period.
\end{abstract}

Keywords Raw material economy · Localization · Diversification · Huayang site · The Late Glacial

\section{Introduction}

Obtaining lithic raw materials is the first step in the sequence of lithic reduction, and also a first step in understanding different lithic technologies. The selection, acquisition, transport,

Shi-Xia Yang

yangshixia@ivpp.ac.cn

1 Department of History, Anhui University, Hefei 230039, China

2 Heilongjiang Provincial Institute of Cultural Relics and Archaeology, Harbin 150008, China

3 University of Chinese Academy of Sciences, Beijing 100049, China

4 Key Laboratory of Vertebrate Evolution and Human Origins, Institute of Vertebrate Paleontology and Paleoanthropology, Chinese Academy of Sciences, Beijing 100044, China

5 CAS Center for Excellence in Life and Paleoenvironment, Beijing 100044, China

6 State Key Laboratory of Loess and Quaternary Geology, Institute of Earth Environment, CAS, Xi'an 710061, China

7 Department of Archaeology, Max Planck Institute for the Science of Human History, 07745 Jena, Germany and management of lithic raw materials can provide significant insight into people's economic activities on the landscape, including their technological organization, mobility patterns, land use strategies, and the extent of their trade and exchange networks (e.g., Andrefsky 1994, 2009; Binford 1979; Adams and Blades 2009; Brantingham et al. 2000; Daffara et al. 2019; Ekshtain and Tryon 2019; Kuhn 2004; Li et al. 2016; Wynn and McGrew 1989; Yang and Yue 2020). In East and Northeast Asia, lithic raw material studies have been extensively conducted to examine the adaptive strategies and behavior patterns of local populations in North China, the Russian Far East, and Japan, especially in the Late Pleistocene (e.g., Du 2003; Gao 2001; Izuho et al. 2017; Kato 2017; Kuzmin et al. 2008, 2013; Li et al. 2016; Ono et al. 2014; Yang et al. 2017a, b).

Northeast China occupies a critical geographic position for understanding exchange networks and interactions among hunter-gatherers in East and Northeast Asia (Fig. 1a). Recently, several studies on lithic raw materials have been integrated into the study of hunter-gatherers' behavioral systems, and most of them focused on the obsidian assemblages distributed in the Changbaishan Mountains (a.k.a. the Paektusan) (Chen et al. 2015; Jia et al. 2010; Li and Chen 2014; Liu et al. 2014). 

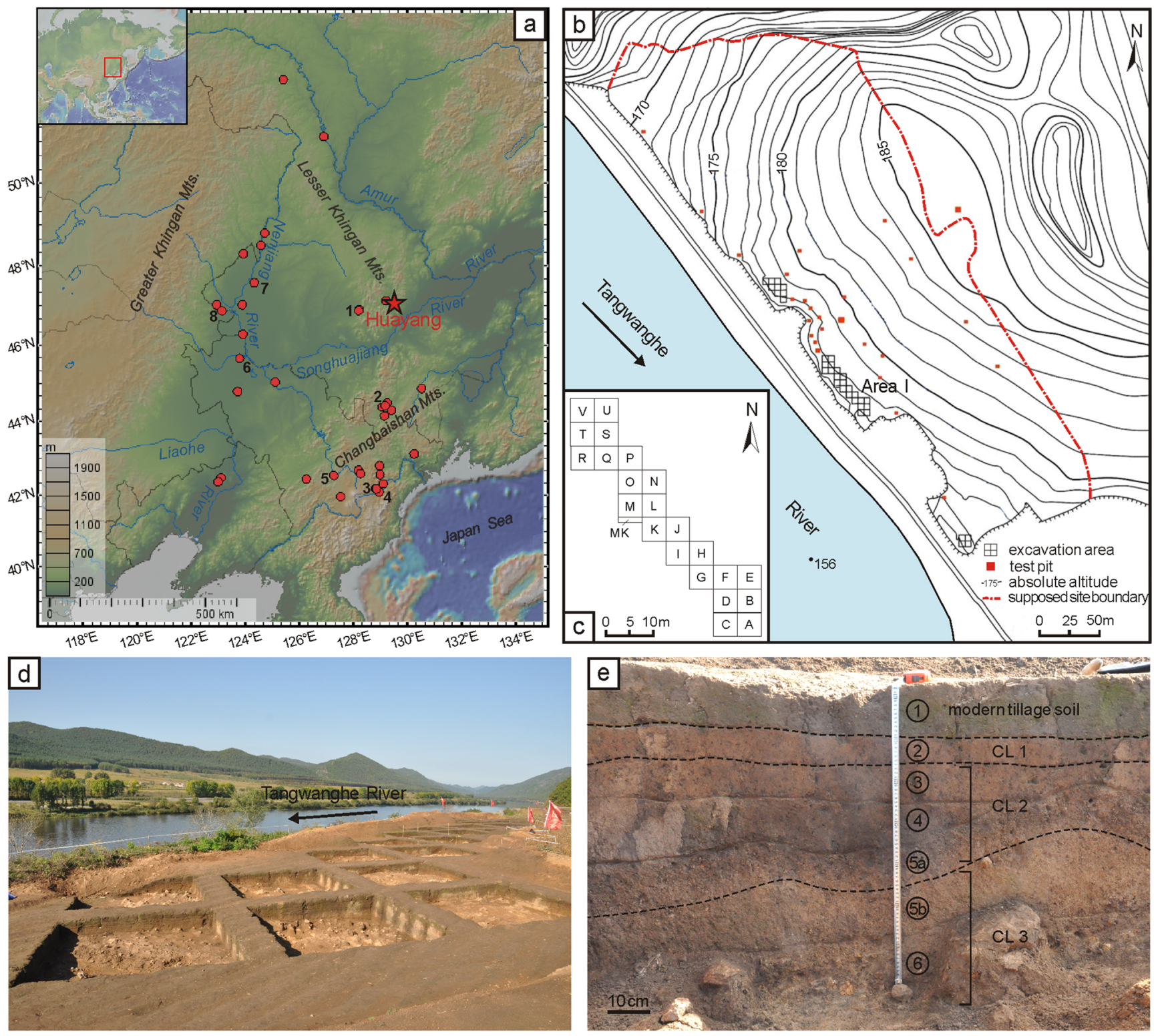

Fig. 1 The Huayang site. a Geographic location of the Huayang site and some other Late Pleistocene sites in Northeast China (1 Taoshan; 2 Xiaolongtoushan; 3 Shirengou; 4 Helong Dadong; 5 Xintunzi Xishan; 6

Based on X-ray fluorescence analysis, researchers argued that Changbaishan obsidian dominates the late Upper Paleolithic assemblages in the central Changbaishan region, at sites such as Helong Dadong, Shirengou, and Xintunzi Xishan, and in some cases has been transported into the Russian Far East and South Korea (Chen et al. 2015; Jia et al. 2010). Meanwhile, the obsidians from the Russian Primorye were also found at several sites in the Changbaishan, suggesting the two-way movement of volcanic glass artifacts between the two regions (Chen et al. 2015; Jia et al. 2010). Kato (2017) defined five late Upper Paleolithic territories in North and Northeast China according to the lithic raw materials found at archeological sites and their site distribution to explore the relationships between human activities and

Houtaomuga; 7 Linfu; 8 Xishantou). b Topographic map of the Huayang site. $\mathbf{c}, \mathbf{d}$ The studied excavation area of the paper. e Stratigraphic profile of the site

their environment. These studies have provided a general understanding of population movement and exchange in Northeast China and neighboring areas, despite relying on an uncertain chronology.

A new series of excavations have recently been undertaken to establish an absolute chronological framework and paleoenvironmental background for the region, at prehistoric sites such as Linfu (Li 2015), Xiaolongtoushan (Li 2019), Xishantou (Liu et al. 2019), Taoshan (Yang et al. 2017a; Yue et al. 2020; Zou et al. 2018), and Houtaomuga (Wang 2018). In particular, based on the lithic assemblages of the Taoshan site (ca. 19-5 ka cal. BP), Yang et al. (2017a) analyzed the lithic raw material 
types and sources through petrological identification and geological prospecting and suggested a correspondence between changes in local lithic raw material exploitation strategies and shifts in environmental settings.

In this paper, we present a detailed analysis of the lithic raw material procurement and exploitation strategies at the Huayang site, which is located approximately $100 \mathrm{~km}$ east of the Taoshan site in the southern Lesser Khingan Mountains (Fig. 1a). Large-scale excavations were undertaken at the site and recovered successive deposits of cultural materials dated to the Late Pleistocene and the Middle Holocene. Here, we focus on the lithic materials that date to $14 \mathrm{ka}$ cal. BP, which form the principal lithic assemblage of the site. In contrast to the earlier studies on obsidian assemblages that have revealed long-distance exchange networks in Northeast China, we combine data from Huayang and neighboring archeological sites to investigate the localization and diversification of lithic raw materials in this region during the Late Glacial period, providing new insight into understanding the economic activities of these populations in a reliable chronological framework.

\section{The Huayang site}

The Huayang site $\left(47^{\circ} 3^{\prime} 52^{\prime \prime} \mathrm{N}, 129^{\circ} 29^{\prime} 40^{\prime \prime} \mathrm{E}\right)$ is located in Yichun County, Heilongiiang Province, on the second terrace of the Tangwanghe River, which cuts through the Lesser Khingan Mountains before it finally flows into the Songhuajiang River. The site is at an elevation of ca. $180 \mathrm{~m}$ above mean sea level and ca. $20 \mathrm{~m}$ higher than the modern Tangwanghe River (Fig. 1).

The Huayang site was found in 2011 when archeologists from Heilongjiang Provincial Institute of Cultural Relics and Archeology conducted archeological surveys associated with the reconstruction of Tieli-Jinshantun and Haonanhe-Nancha highways. In the following year, Huayang was excavated in a large scale as a salvage archeological project. Approximately $1000 \mathrm{~m}^{2}$ of the site was exposed in three excavation areas (labeled I, II, and III) and several test pits (Fig. 1b).

Area I, as the primary excavation area, covers a total of $555 \mathrm{~m}^{2}$, which is divided into squares $\mathrm{A}-\mathrm{V}(5 \mathrm{~m} \times 5 \mathrm{~m})$ along with square MK $(1 \mathrm{~m} \times 5 \mathrm{~m})$ opened as the extension of square M (Fig. 1c, d). From the stratigraphic sequence of the site, three prehistoric cultural layers (CL1, 2 , and 3; Fig. 1e) were identified on the basis of sedimentary facies and artifact concentration. Respective dates of 5992-5916, 14,355-14,025, and 18,614-17,885 cal. BP for CL1, CL2, and CL3 have been suggested by radiocarbon dating on charcoals recovered from the cultural layers (Yue et al. 2019).

\section{Materials and methods}

\section{Raw material identification and geological survey}

We examined archeological materials from Huayang CL2, which contained a total of 18,477 pieces of lithic artifacts that have maximum length $>10 \mathrm{~mm}$. The methods of raw material identification and provisioning are the same as described by Yang et al. (2017a), based on petrological observations and archeologically oriented surveys for sources.

Macroscopic and microscopic observations were used to identify different types of raw materials. First, each material was classified by macroscopic observation according to color and texture. Following this, selected samples were submitted for microscopic observation with the application of a petrographic polarizing microscope. A polarizing microscope, with plane polarized light and perpendicular polarized light, was used to collect images of the texture of the raw materials, which helped identify the different rock types as well as evaluate the quality of raw materials.

In order to identify raw material sources, we conducted a geological prospecting survey using a 1:200,000 geological map of the region (Fig. 2a). The bedrock outcrops around the site were easily accessible because of highway construction projects. As shown in Fig. 2a, the survey area covers the easternmost point near the confluence of the Zhulabilahe River and its branch and the north-westernmost point near the Lvhua village. Each occurrence of raw materials was registered via GPS, photographed and described. Raw material samples were collected from riverbeds and bedrock outcrops, and afterwards compared with archeological materials based on petrological analysis. The natural surfaces (e.g., cortex, weathered surface) of the archeological materials were also recorded in order to determine whether the lithic raw materials of Huayang were derived from primary outcrops or secondary deposits.

\section{Lithic raw material economy, spatial distribution, and refitting}

Based on the results of Yue et al. (2019)'s techno-typological analysis, we followed the techno-economy protocol to investigate the lithic raw material economy of the site (e.g., Inizan et al. 1999; Soressi 2002; Soressi and Geneste 2011). Within the raw material categories, the knapping techniques and methods are identified through a technological reading of each object. Following this, we can reconstruct the chaîne opératoire of the assemblage and determine whether each step of the operational sequence is present at the site.

Furthermore, we integrate the raw material and technotypological information with the three-dimensional data of lithic artifacts to investigate the intra-site spatial organization pattern. The tridimensional location of remains and the wide 

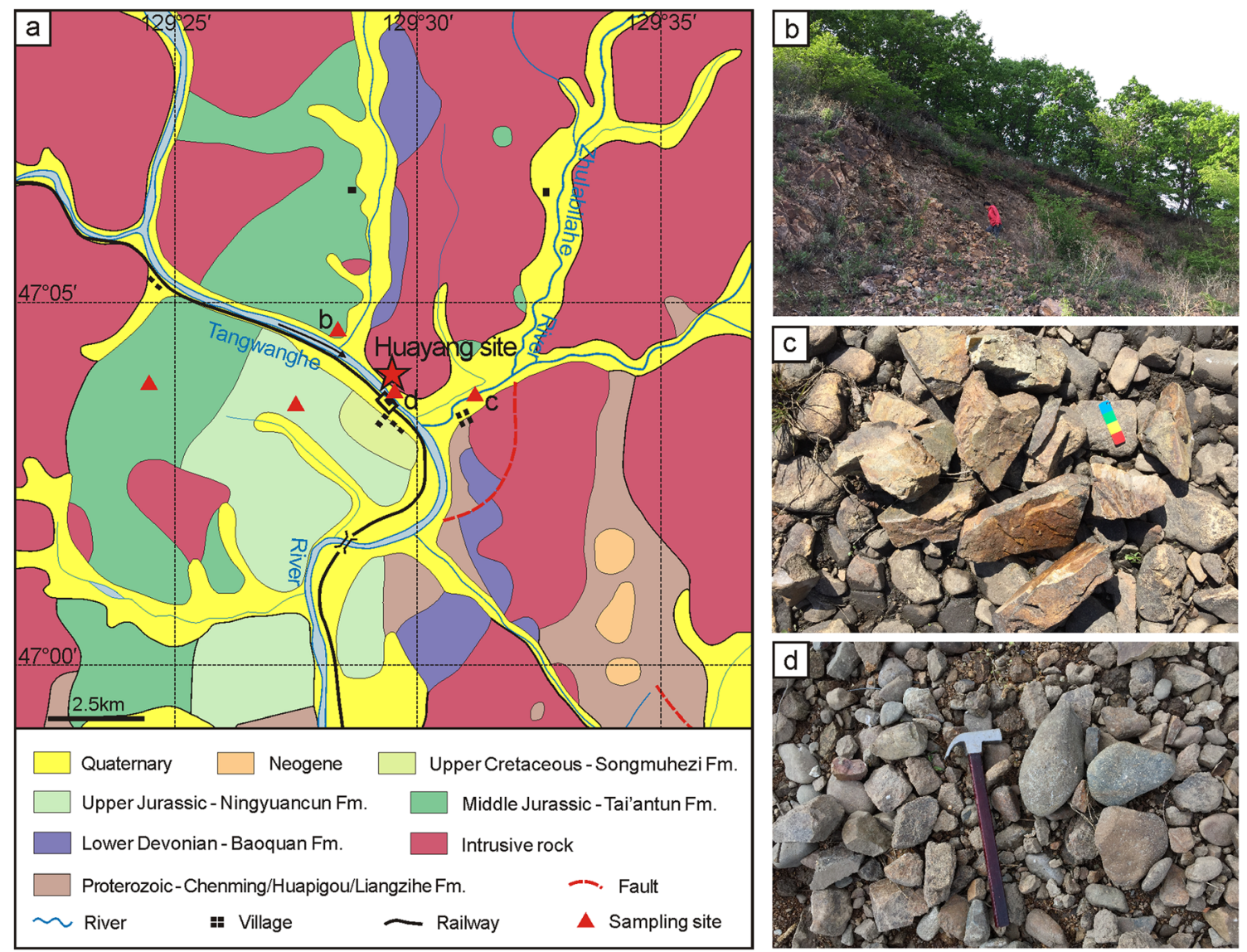

Fig. 2 Geological map and field photographs around the Huayang site. a Geological map around the Huayang site. b Geological outcrop of the the Zhulabilahe River. d Gravels of different sizes from the Tangwanghe River

Tai'antun Formation (a modern local quarry pit). c Rhyolite blocks from

excavation of surfaces guarantee the identification of spatial units at the site.

Refitting practices have also been carried out at the Huayang site to clarify stone knapping strategies and intrasite spatial organization. Considering the huge number of specimens and time limitation, we mainly focused on the lithic artifacts with technical and/or raw material particularities, especially on dacite artifacts and bifacial points. In describing refitting artifact sets, we follow the differentiated use of refit and conjoin (Cziesla 1990; Sisk and Shea 2008).

\section{Results}

\section{Raw material types}

The raw materials of Huayang CL2 are categorized on the basis of macroscopic observations and petrological analysis results. As shown in Table 1, the lithic assemblage is dominated by banded rhyolite $(90.25 \%)$, followed by felsite $(17.21 \%)$ and felsophyre $(10.95 \%)$. Other raw materials, including shale, dacite, tuff, agate, and chert, occur in low frequencies.
Rhyolite, the most favored raw material for artifact production at Huayang, is a kind of extrusive igneous rock mineralogical equivalent to granite and has aphanitic to porphyritic texture chiefly with quartz and sanidine appearing as phenocrysts. According to microscopic features, rhyolites at the Huayang site can be generally divided into two sub-types. One is banded rhyolite, named for its characteristic banded structure (Fig. 3a). The other is felsite, with few or absence
Table 1 Lithic raw site (modified from Yue et al. 2019) materials of the Huayang

\begin{tabular}{lll}
\hline Raw materials & Number & Percent \\
\hline Banded rhyolite & 11,472 & 62.09 \\
Felsite & 3180 & 17.21 \\
Felsophyre & 2023 & 10.95 \\
Shale & 587 & 3.18 \\
Dacite & 488 & 2.64 \\
Tuff & 277 & 1.50 \\
Agate & 119 & 0.64 \\
Chert & 93 & 0.50 \\
Others & 238 & 1.29 \\
Total & 18,477 & 100 \\
\hline
\end{tabular}



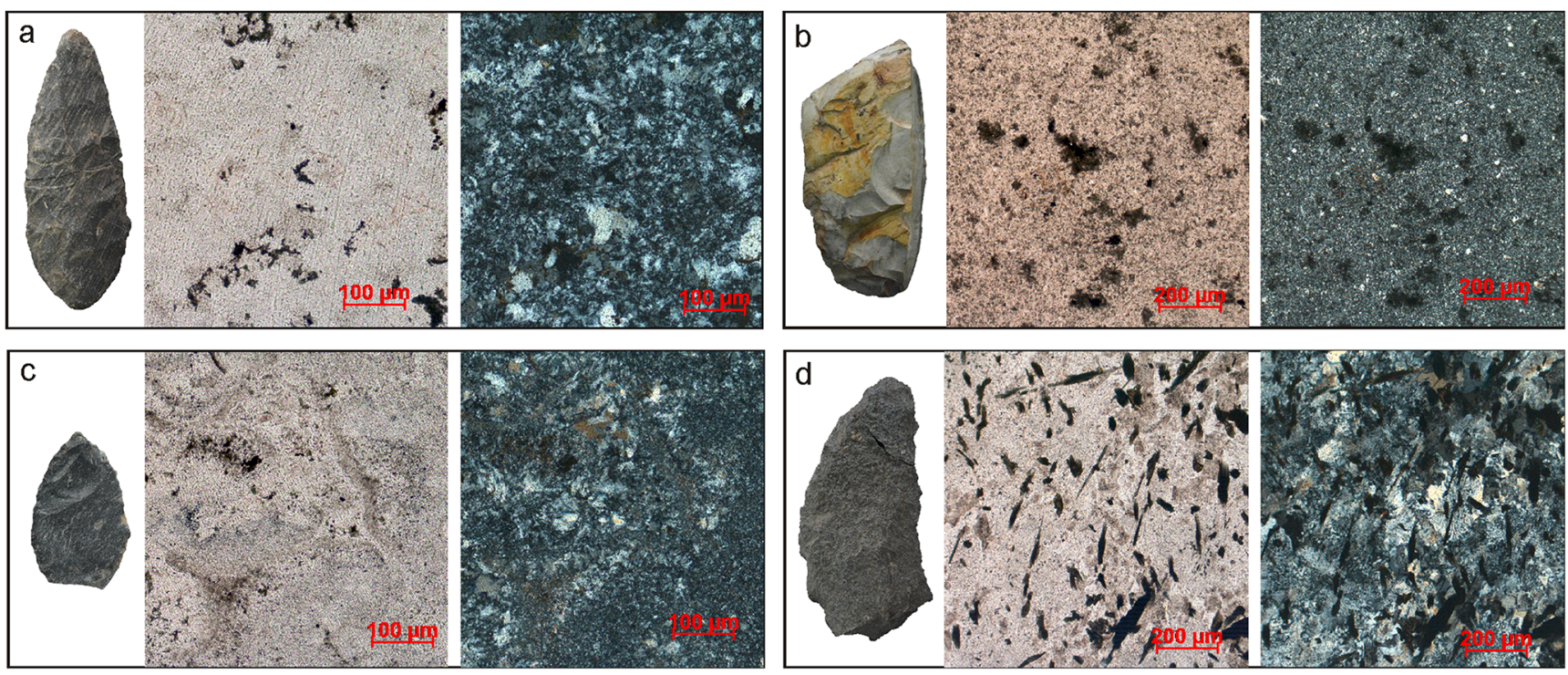

Fig. 3 Photomicrographs of the main rock types from the Huayang site. a Banded rhyolite. b Felsite. c Felsophyre. d Dacite

of porphyritic texture, while felsitic texture in the matrix can be observed (Fig. 3b). Generally, both banded rhyolite and felsite can be described as fine-grained materials that allow for good conchoidal fracture.

Felsophyre, a porphyry with microcrystalline groundmass containing some glass (Fig. 3c), also comprises a significant portion of the Huayang assemblage. This material is finegrained and dense and is an excellent lithic raw material. In addition, the raw materials, including tuff, agate, and chert, are rich in silica and suitable for knapping activities, which are also widely procured and exploited at other archeological sites in Northeast China (Dong 1989; Huang et al. 1984; Li 2012; Yue et al. 2017, 2020).

In contrast, dacite, as an extrusive igneous rock and the equivalent of granodiorite, usually has porphyritic texture (Fig. 3d). The phenocrysts mainly contain plagioclase, quartz, and other crystalline minerals. The texture of dacite is generally coarse-grained, which may limit the application of certain knapping techniques. At the Huayang site, dacite was procured in small amounts, making up $2.64 \%$ of the whole assemblage.

\section{Raw material sources}

According to geological maps and reports, the Tai'antun, Ningyuancun, and Songmuhezi formations, located west of the Huayang site with minimal distance within $3 \mathrm{~km}$, contain several kinds of igneous rocks, especially rhyolite, felsophyre, tuff, lava, porphyrite, and andesite (Fig. 2a; Bureau of Geology and Mineral Resources of Heilongjiang Province 1993). During the field survey, we identified several bedrock outcrops exposed by construction activities (Fig. 2b). Igneous rocks, such as rhyolite, felsophyre, and tuff, were primarily from these formations and clearly visible on the outcrops.
In addition, we found that all the raw material types in the Huayang assemblage can be found in secondary sources near the site (Fig. 2c, d). Along the riverbeds of the Tangwanghe and Zhulabilahe rivers, the pebbles and cobbles in felsophyre, dacite, crystal tuff, agate, and chert are well rounded (Fig. 2d), while other raw materials, including felsite and banded rhyolite, are usually in the form of angular blocks with the scarcity or absence of cortex, indicating short-distance transport from the primary outcrops (Fig. 2c). Further comparative identification suggests that the correspondence between the survey samples in primary or secondary context and the archeological materials is quite good, showing a pattern of local raw material provisioning at the site.

The presence or absence of natural surfaces on the lithic artifacts from Huayang was recorded for further distinguishing the raw materials from secondary to primary sources. As shown in Table 2, the relatively high and moderate frequency of rolled pebble cortex shows that the majority of raw materials, including felsophyre, dacite, crystal tuff, agate,

Table 2 Counts and frequencies of the lithic artifacts with natural surface at Huayang

\begin{tabular}{llllll}
\hline \multirow{2}{*}{ Raw materials } & \multicolumn{2}{l}{ With cortex } & & \multicolumn{2}{l}{ With weathered surface } \\
\cline { 2 - 3 } \cline { 6 - 6 } \cline { 5 - 6 } & $n$ & $\%$ & & $n$ & $\%$ \\
\hline Banded rhyolite & 75 & 0.65 & & 356 & 3.1 \\
Felsite & 62 & 1.95 & & 980 & 30.82 \\
Felsophyre & 182 & 9.0 & & - & - \\
Dacite & 200 & 40.98 & & - & - \\
Crystal tuff & 94 & 33.94 & & - \\
Agate & 37 & 21.01 & - & - \\
Chert & 25 & 39.78 & - & - \\
\hline
\end{tabular}


and chert, came from riverbeds or from gravel layers of the terraces. In contrast, felsite artifacts have a low percentage of cortex $(1.95 \%)$ but relatively high frequency of weathered surfaces $(30.82 \%)$, showing similarities with the angular felsitic blocks found in the local riverbeds. Very few natural surfaces, no matter cortex $(0.65 \%)$, or weathered surface (3.1\%), were observed on banded rhyolites. In consideration of the abundance of banded rhyolites in the riverbeds near the site, we suggest that this kind of material was probably procured from nearby river boulders.

By combining the data of natural surfaces on the artifacts and the results of geological survey and petrological identification, we suggest that the Huayang inhabitants exploited lithic resources from the local riverbeds within $2-3 \mathrm{~km}$.

\section{Procurement patterns and reduction sequences of raw materials}

The techno-typological analysis revealed that the Huayang lithic assemblage comprises diversified technologies (Table 3; Fig. 4; Yue et al. 2019). Core-flake and bladelet reductions constitute two main debitage sequences, while microblade reduction only consists of a minor proportion. The toolkit is characterized by the dominance of bifacial points and the appearance of new tool types, including arrowheads, axes, adzes, ground chisels, and grinding stones.

The lithic raw material compositions of different lithic technologies at Huayang are shown in Fig. 5. In general, cores of core-flake technology are dominated by felsite, but flakes are mostly in banded rhyolite. In the bladelet reduction, felsite shows an absolute majority. Two main materials, felsite and chert, characterize the microblade reduction. In contrast to the bifacial points which are predominated by banded rhyolite, other tools are fairly variable in terms of raw material selection. Overall, different exploitation patterns were involved in

Table 3 The lithic assemblage composition (> $10 \mathrm{~mm}$ ) of the Huayang site (modified from Yue et al. 2019)

\begin{tabular}{lll}
\hline Categories & Number & Percent \\
\hline Core & 42 & 0.23 \\
Flake and flake fragment & 12,209 & 66.08 \\
Bladelet core & 33 & 0.18 \\
Bladelet and characteristic by-product & 489 & 2.65 \\
Microblade core & 2 & 0.01 \\
Microblade and characteristic by-product & 13 & 0.07 \\
Bipolar piece & 7 & 0.04 \\
Tool & 243 & 1.31 \\
Angular fragment and shatter & 5426 & 29.37 \\
Unmodified piece & 13 & 0.07 \\
Total & 18,477 & 100 \\
\hline
\end{tabular}

coping with different raw materials at the site, leaving behind abundant characteristic products with which we could reconstruct the chaine opératoire of the whole assemblage (Fig. 6).

As shown in Fig. 6, banded rhyolite, the dominant raw material at Huayang, was mainly used for bifacial point production. According to morphometric data, most cores (mean = $46.71 \mathrm{~mm}$ ) and flakes (mean $=22.5 \mathrm{~mm}$ ) in banded rhyolite are relatively small in maximum length in comparison with complete bifacial points $($ mean $=71.01 \mathrm{~mm})$, indicating that large-sized flakes which could have been primarily introduced into the site ready-made were selected as tool blanks. Hardhammer and follow-on soft-hammer percussion have been suggested for the manufacture of bifacial points (Yue et al. 2019). On the other hand, banded rhyolite was used for flake debitage as well, though in very low proportions (Fig. 6). Three pieces of cores are present and show a simple coreflake debitage method. In terms of tool manufacture, retouched pieces other than bifacial points are represented by 35 pieces and show a wide range of types, including scrapers, endscrapers, denticulates, borers, burins, and arrowheads, among which flakes are exclusively used as tool blanks.

The felsite exploitation strategies are clearly different from those of banded rhyolite. Two main reduction sequences of felsite have been identified (Figs. $4 \mathrm{~b}$ and 6 ). One is optimized towards bladelet production. The felsitic blocks were procured and systematically shaped-out. Afterwards, indirect percussion was applied for bladelet removal (Yue et al. 2019). The other reduction sequence is towards the production of flakes. Although there are different core types, core shaping is generally simple and expedient. Tools are mainly represented by scrapers and points and show a large proportion of flake blanks, with only two pieces on bladelet.

Felsophyre and crystal tuff were used as a supplement to banded rhyolite and felsite in the knapping activities of core-flake and bladelet debitage and follow-on tool production (Figs. 4c and 6). The same circumstance also applies for chert, which was utilized with a variety of reduction strategies though chert artifacts make up just $0.5 \%$ of the whole assemblage (Fig. 6). In particular, two microblade cores made of chert are identified and exhibit a wedge-like morphology and a bifacial shapingout process. In contrast, dacite was exclusively used for flake debitage and subsequent tool manufacture in a very simple and expedient manner (Figs. $4 \mathrm{~d}$ and 6). Cores and flakes in dacite show clear evidence of hard-hammer direct percussion and an informal debitage method, and retouched tools represented by two scrapers and one notch exhibit very simple forms.

In addition, other raw materials were also exploited for specific reduction objectives, though all present in small amounts. For example, agates were mostly transformed to flakes and bipolar splinters with the respective application 

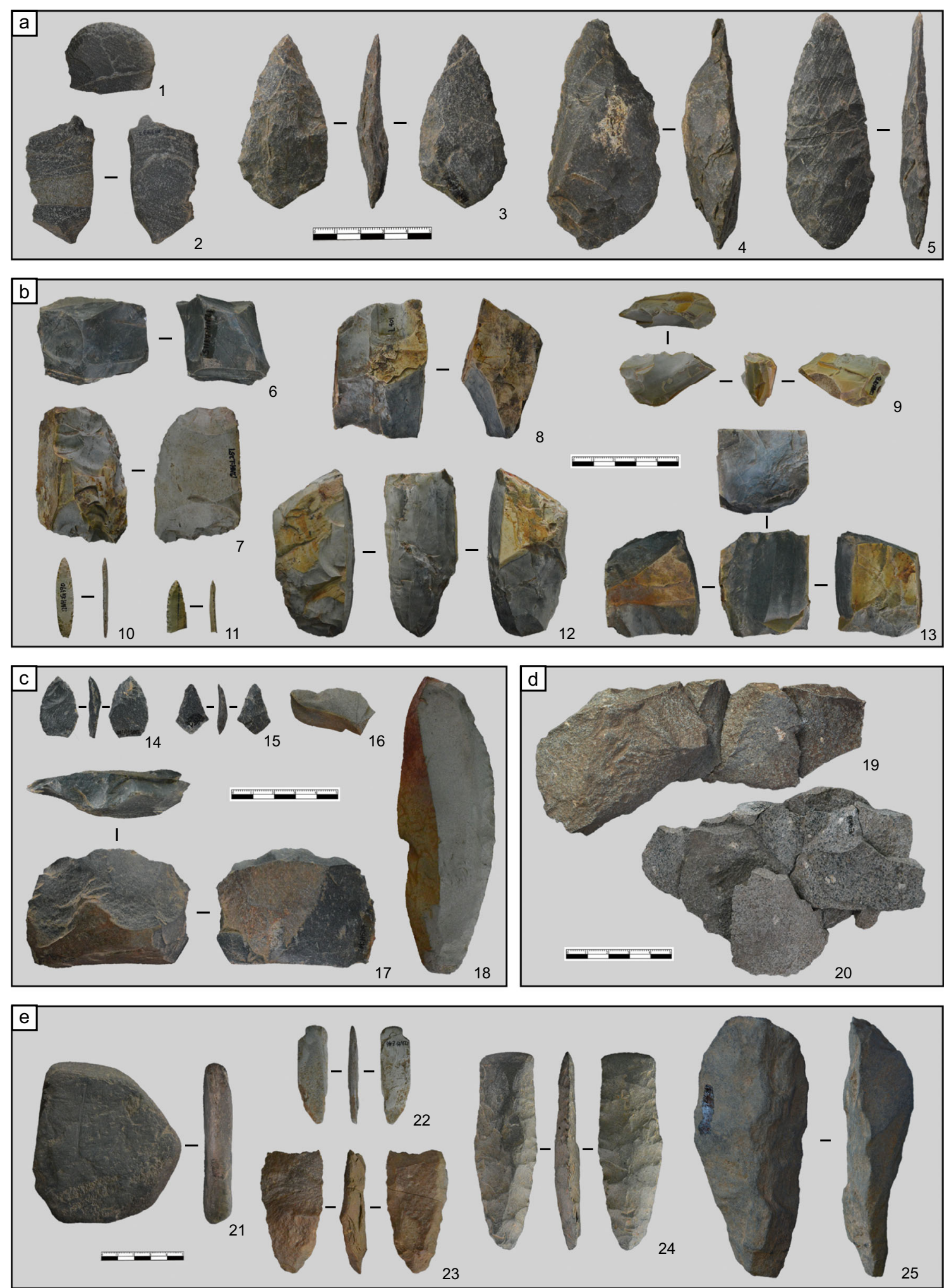

Fig. 4 Lithic artifacts by raw material at the Huayang site (modified from Yue et al. 2019). a Banded rhyolite. b Felsite. $\mathbf{c}$ Felsophyre and tuff. d Dacite. e Other raw materials

of direct percussion and bipolar technique. Oval-shaped cobbles in quartz sandstone, granite, and diorite were selected as hammer stones; tabular cobbles in sandstone were procured as grinding stones. The formal tools including axes, adzes, and chisels were usually made from tuffaceous sandstone, quartzite, and diorite (Fig. 4e). 


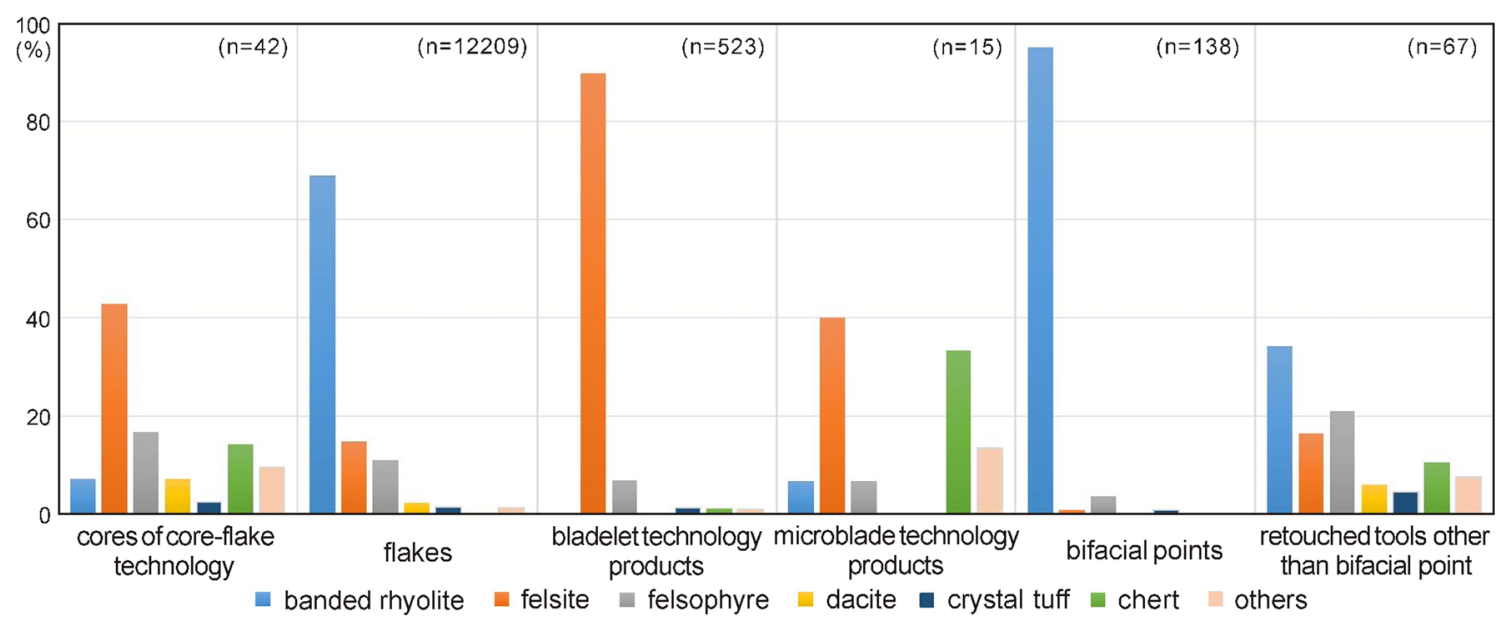

Fig. 5 Lithic raw material composition of different lithic technologies at the Huayang site

In sum, the coexistence of diversified technical products characterizes the Huayang lithic assemblage. The toolkit comprises not only the traditionally Upper Paleolithic artifacts but some new tool types. Furthermore, it is remarkable that different knapping strategies were applied for processing different raw materials at the site, showing respective reduction sequences as detailed above.

\section{Spatial distribution and raw material exploitation}

As shown in Fig. 7, there is a clear differential distribution of lithic remains that are clustered in well-delimited accumulations. The overwhelming majority of artifacts found at the Huayang site are concentrated in these areas.

In general, the spatially delimited accumulations contain different raw materials. Taking square A-D for example, eight accumulations (labeled A1-A8) have been identified, among which $\mathrm{A} 1, \mathrm{~A} 2, \mathrm{~A} 3, \mathrm{~A} 5$, and $\mathrm{A} 7$ are characterized by shale, tuff, felsite, tuffaceous sandstone, and felsophyre, respective- ly, but A4, A6, and A8 are by banded rhyolite (Fig. 7c). In addition, some inter-accumulation differences have been detected concerning lithic techno-typological composition. Bladelet debitage products are well represented at A3, while almost absent from other accumulations (A1, A2, and A5A8). Accumulations of A4, A6, and A8 are characterized by the abundance of flakes and flake fragments made on banded rhyolite and especially the presence of bifacial points with a total number of 59 pieces. These differences can be attributed to the spatially partitioned distribution of knapping activities of different raw materials. Products of all stages within each reduction sequence present at the site are represented by corresponding accumulations and are dominated by small-sized debitage products, indicating that there is virtually an entire process of stone reduction sequences at all accumulations and that knapping activities were carried out in situ.

Refitting practices are in line with this conclusion as well. In our study, we obtained 45 conjoined groups and 23 refitted groups involving a total of 159 stone artifacts which com-

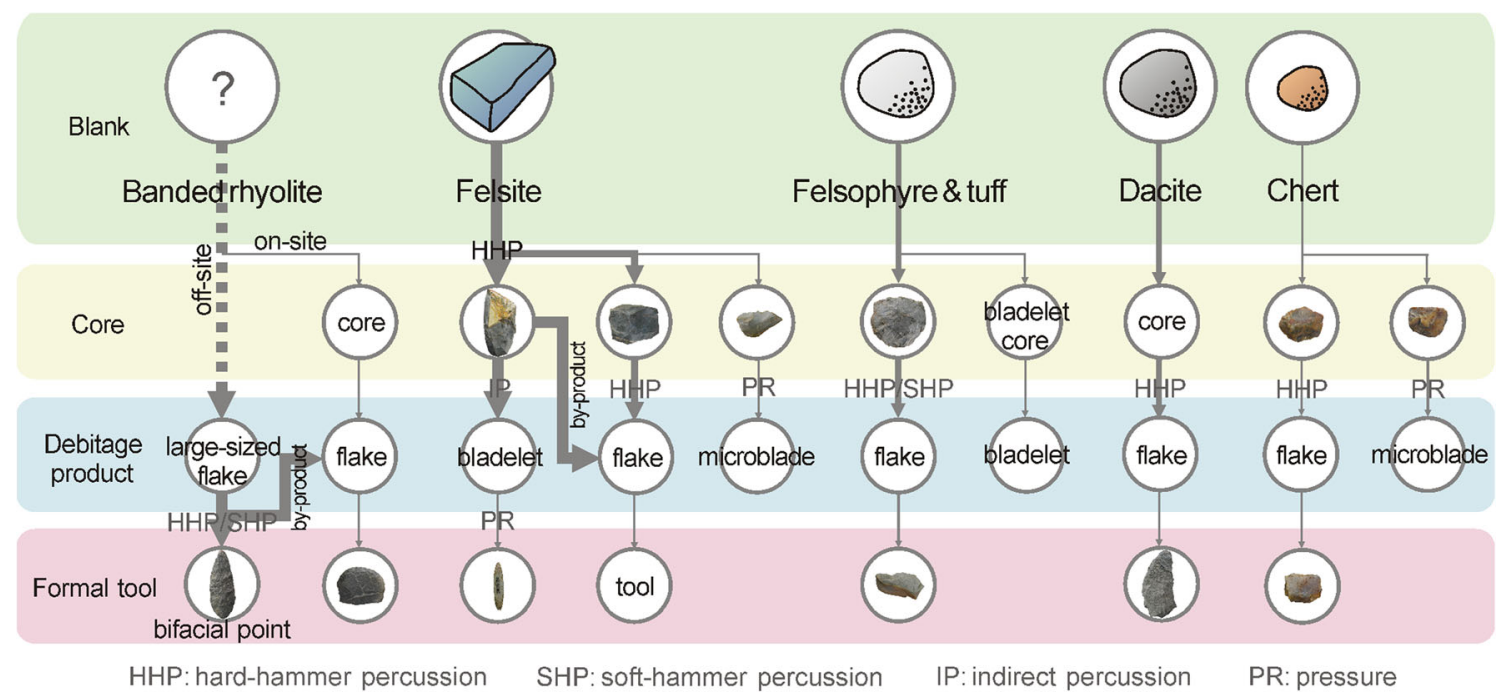

Fig. 6 Main reduction sequences by raw material at the Huayang site 


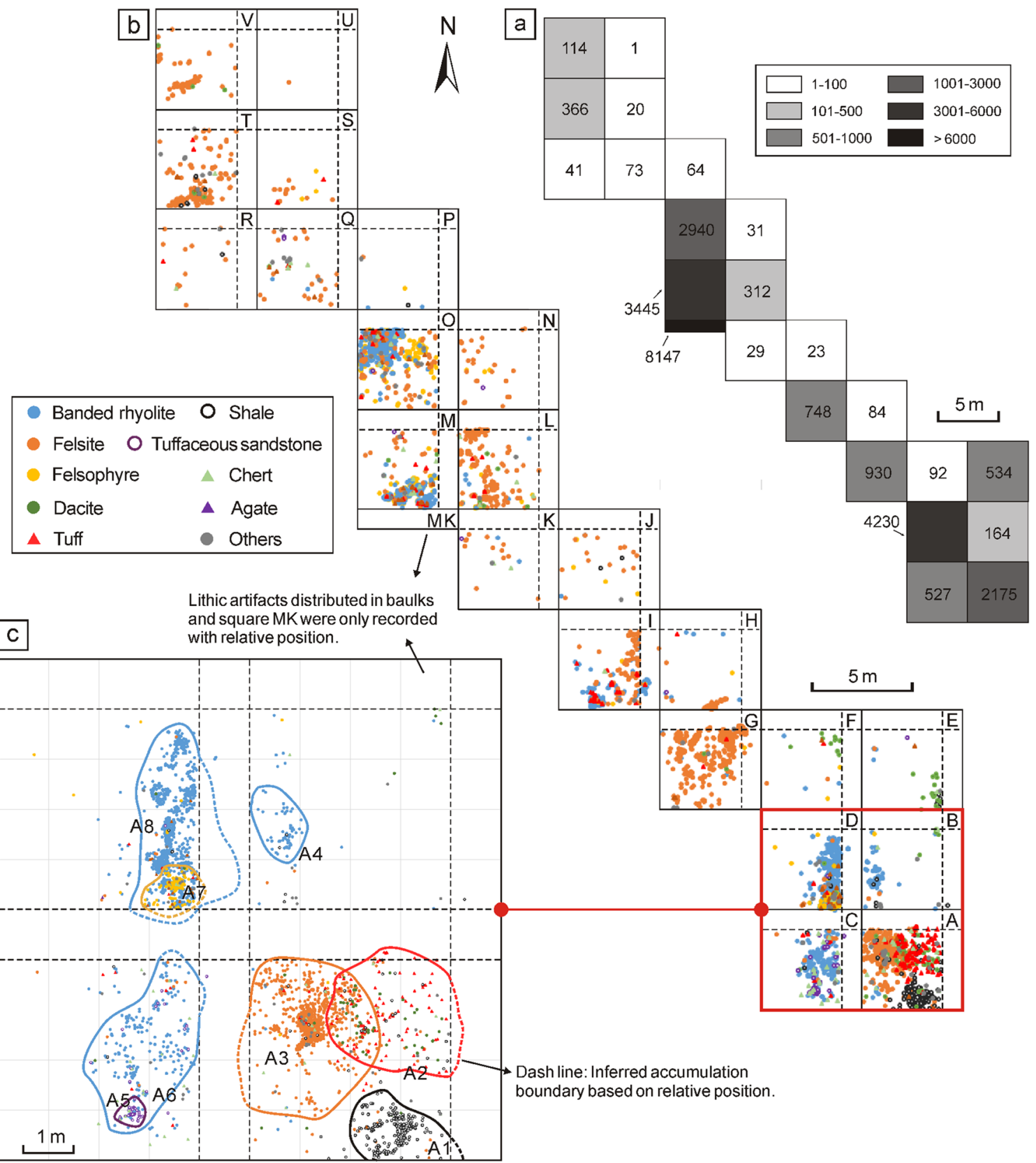

Fig. 7 Spatial distribution of lithic remains at the Huayang site

prised varied technical products, such as cores, flake/bladelet debitage products, tools, and angular fragments. Specifically, 11 connections between 23 bifacial points and 17 associations between 48 dacite artifacts have been identified, accounting for $16.67 \%$ and $9.84 \%$ of the respective whole sample. All the artifacts in each refitting group are generally concentrated in the same accumulation, and the distance between each connection is fairly small, with most $<0.5 \mathrm{~m}$ (Fig. 8).

Overall, different delimited areas can be recognized at the site, which indicate in situ preservation of all the reduction sequences carried out at the site. It is also highlighted that there is a strong discrete spatial pattern for each of the different raw materials that were reduced towards respective objective products.

\section{Discussion and conclusions}

\section{Lithic raw material economy of Huayang}

Generally, people at Huayang relied exclusively on local materials. Lithic resources derived from local riverbeds were carried to the site for further processing. Together, raw material, techno-typological, and spatial analyses all indicate that nearly 

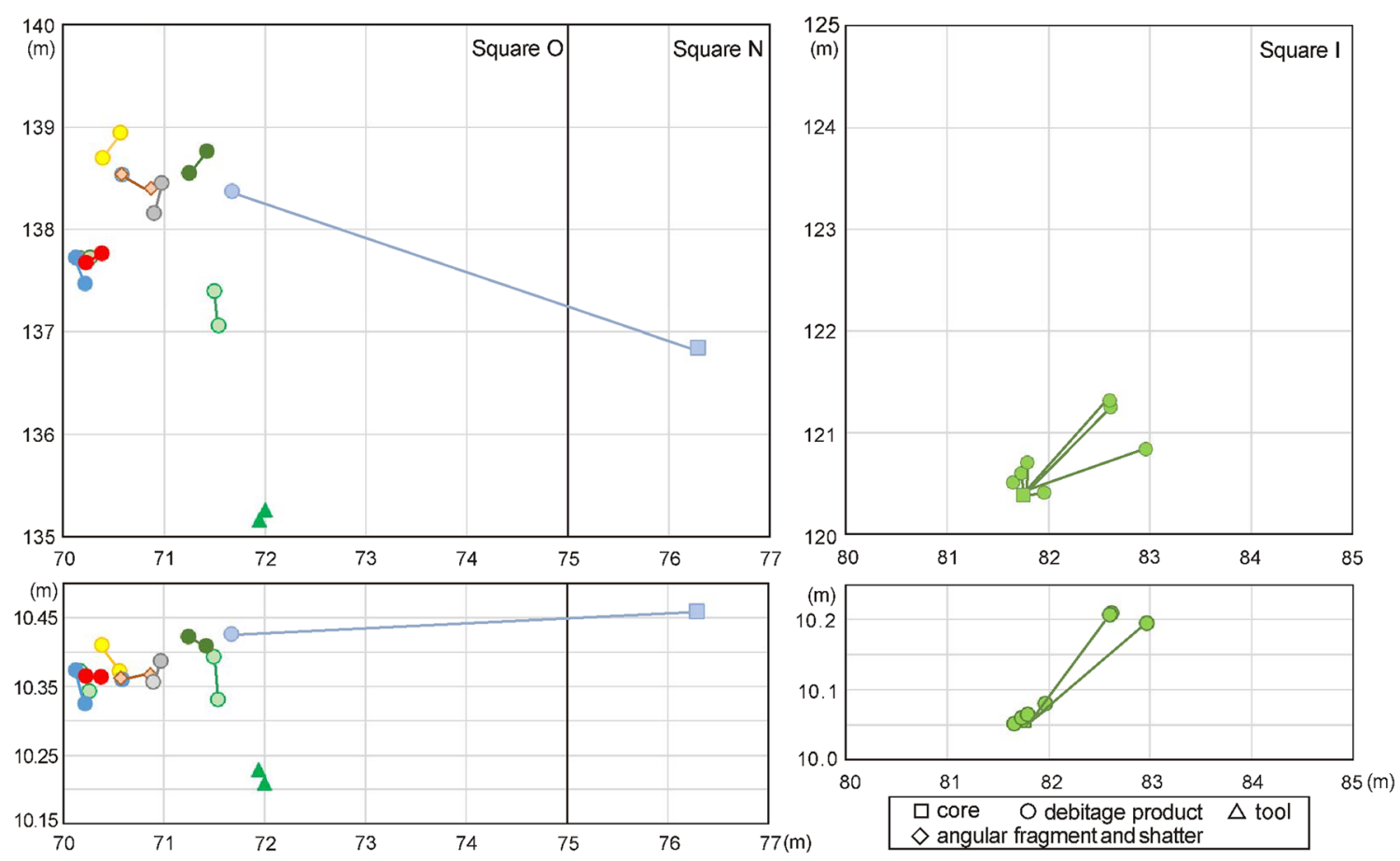

Fig. 8 The plan and profile of refit groups at the squares I, N, and O of the Huayang site

the whole sequence of reduction activities, including core preparation, blank debitage, and tool manufacture, took place on site. The only exception is that banded rhyolite, which was primarily procured for bifacial point production, could have been introduced into the site as ready-made flakes to be further reduced at the site. Based on all these data, we interpret the Huayang site primarily as a well-preserved knapping workshop, revealing a vivid portrait of how the local lithic raw materials were used around $14 \mathrm{ka} \mathrm{cal}$. BP.

Cortex coverage, artifact size, and retouch frequency are commonly used variables to assess the intensity of raw material exploitation (e.g., Blades 2001; Dibble 1995; Douglass et al. 2008; Gao 2001; Kuhn 2004; Li et al. 2016; Lin et al. 2015). At the Huayang site, numerous lithic artifacts show the presence of natural surfaces. Though small-sized pieces dominate the whole assemblage, cores of both core-flake and bladelet debitage are relatively large and mostly have the potential for further reduction. In addition, approximately $76.19 \%$ of the cores bear natural surfaces. The ratio of formal tools to cores and flakes is also very low. All these observations indicate that the intensity of raw material consumption at the site is low, which is usually seen at sites located close to raw material sources.

Though lithic raw materials were not fully consumed at the site, it is evident that different strategies were involved in coping with different raw materials. From a macro view, the data from the Huayang assemblage clearly indicate the parallel use of two technological strategies: informal designs for low-quality raw material (dacite), and both informal and formal for high-quality raw materials, such as rhyolite, felsophyre, tuff, and chert. This observation is consistent with theoretical expectations on the relationship between lithic technology and raw material quality and availability (Andrefsky 1994). From the micro perspective, we noted that different high-quality raw materials were used for different end products and were reduced in spatially delimited areas. Banded rhyolite, for example, was predominantly transformed into bifacial points with the application of soft-hammer percussion, while felsite was mainly for bladelet production by punch technique. The internal properties of lithic raw materials, especially elasticity, might account for these observations, while it remains to be testified by further experimental and quantitative analysis.

On the whole, at ca. $14 \mathrm{ka}$ cal. BP, the Huayang site primarily served as a knapping workshop where almost all knapping activities took place on site. Diversified lithic raw materials were procured from the local riverbeds around $2-3 \mathrm{~km}$ from the site. Despite the overall low consumption intensity, different lithic raw materials were reduced towards respective end products at differentiated accumulations of the site, indicating strong raw material preference and clear technological and spatial organization patterns.

\section{Lithic resource localization and diversification as adaptive strategies}

The Huayang site contains successive prehistoric deposits spanning from ca. $18.6 \mathrm{ka}$ to $6 \mathrm{ka}$ cal. BP. Temporal trends 
during the Late Pleistocene can be detected in the Huayang assemblages when taking the lithic assemblage of earlier phase into consideration. During the first phase (Huayang CL3), between ca. 18.6 and $17.9 \mathrm{ka}$ cal. BP, a total of 40 pieces of stone artifacts were retrieved and predominantly made on high-quality felsophyre, felsite, and chert. The types mainly include microblade cores, flakes, bladelets, and elaborately retouched pieces, such as scraper, burin, end-scraper, and borer, which show clearly curated technologies (Yue 2019). When it came to ca. $14 \mathrm{ka}$ cal. BP (Huayang CL2), as detailed above in this paper, diversified lithic raw materials of local origins were provisioned in large quantities and exploited with differentiated strategies.

Other contemporaneous sites in the southern Lesser Khingan Mountains, especially the Taoshan site, also contain similar diachronic changes in lithic resource exploitation (Yang et al. 2017a; Yue et al. 2020). During the first occupation phase of Taoshan (ca. 19-16.5 ka cal. BP), a small sample of lithic artifacts were found. Fine-grained vitric tuff, derived from a geological outcrop some 5-10 km from Taoshan, was brought into the site and was primarily found among the microblade debitage. During the latter phase (ca. 15$14 \mathrm{ka} \mathrm{cal}$. BP), lithic artifacts densified and tool type variability increased. New tool types such as axes and adzes emerged in the toolkits. In addition, lithic resource procurement strategy shifted towards the selection of varied raw material types from gravel deposits in close proximity to the site (Yang et al. 2017a; Yue et al. 2020).

Huayang and Taoshan are roughly contemporaneous and altogether represent a trend towards localization and diversification of lithic sources during the Late Glacial. On one hand, prehistoric hunter-gatherers in the southern Lesser Khingan Mountains localized the procurement of lithic resources of different types and qualities after ca. $15 \mathrm{ka}$ cal. BP. On the other hand, different knapping strategies were applied for different raw materials. In particular, a new technique - grinding - was used to finish the newly made tools, such as axes, adzes, and chisels, resulting in the coexistence of ground and flaked stone tools at the sites. In addition, this general trend was accompanied by the appearance of pottery not only at these two sites but also in neighboring regions including the Song-Nen Plain and the middle and lower Amur River basin (Kuzmin 2014; Sato and Natsuki 2017; Wang 2018; Wang and Sebillaud 2019; Yue et al. 2020), which signaled a substantial shift in human subsistence patterns (Kunikita et al. 2013, 2017; Shoda et al. 2020). With reference to the theoretical expectations on relations between technological organization and settlement mobility (Binford 1979; Kelly 1992; Nelson 1991; Parry and Kelly 1987; Shott 1986), we suggest that the technological changes in the southern Lesser Khingan Mountains were likely the result of the decrease of mobility, as well as of the change in land use patterns shifting from residential to logistical mobility.
The changes in mobility and land use patterns seem to have been associated with paleoclimatic and paleoenvironmental shifts (see also Yang et al. 2017a; Yue et al. 2019). Although a paleoenvironmental framework cannot be established using the present paleoenvironmental materials from Huayang, given the poor preservation of sporopollen and phytoliths, a series of high-resolution complexes in neighboring sites (e.g., the Taoshan) and areas have well understood vegetation histories and climatic events ( $\mathrm{Li}$ et al. 2019; Mingram et al. 2018; Stebich et al. 2009; Wu and Liu 2013; Wu and Shen 2010; Wu et al. 2016; Yang et al. 2017a). During the Late Glacial, climatic and environmental conditions ameliorated significantly at ca. $15 \mathrm{ka}$ cal. BP, corresponding with the start of the BøllingAllerød phase. The increasing site numbers and intra-site artifact densities in the southern Lesser Khingan Mountains indicate that demographic expansion occurred during this period (Yang et al. 2017a), which is further testified by the archeological and genetic evidence in the context of East and Northeast Asia (Buvit et al. 2016; Kudo and Kumon 2012; Wang et al. 2014; Zheng et al. 2011). Under such circumstances, the imbalance between population size and natural resources probably began to accelerate, which could have prompted foragers to decrease mobility and innovate technological strategies towards diversified and intensified exploitation of local floral, faunal, and lithic resources.

In conclusion, the site of Huangyang well preserved a knapping workshop dating to ca. $14 \mathrm{ka} \mathrm{cal}$. BP, and, together with the neighboring archeological sites, provided thorough data to reveal the localization and diversification of lithic raw materials in the southern Lesser Khingan Mountains of Northeast China during the Late Glacial. These changes appeared as the result of the decrease of human mobility and had its roots in the paleoclimatic amelioration and the demographic expansion during this period. In broader geographical contexts, Northeast China accumulates large quantities of cultural remains and shows sharp ecological contrasts, making it an interesting region for exploring the behavior patterns and adaptive strategies of prehistoric hunter-gatherers in different ecosystems. Moreover, the critical geographic location of Northeast China gives it great significance for the study of the interaction among human groups in East and Northeast Asia and their expansion into the Americas. Further systematic excavations, well-dated cultural features, and more multidisciplinary analyses linking paleoecology and huntergatherer adaptation will help elaborate on these issues.

Acknowledgments Our warmest appreciation goes to M.J. Storozum from Max Planck Institute for the Science of Human History for proofreading and insightful comments on the earlier draft. We also thank P. Chen from Wuhan University, X.W. Zhang, Y. Liu, and S.Q. Chen from Heilongjiang University, and L. Lei from University of Chinese Academy of Sciences for contributions to lithic study and geological survey. Many thanks to the editor, Professor N. Conard, and three reviewers for their constructive suggestions to improve our manuscript. 
Authors' contributions S.X.Y., Y.Q.L. and J.P.Y. designed the research. Y.Q.L., J.P.Y. and Y.X.Z. collected the data. S.X.Y., J.P.Y. and Y.X.Z. performed the analysis. J.P.Y. and S.X.Y. wrote the paper.

Funding information Open access funding provided by Projekt DEAL. This research was funded by the Strategic Priority Research Program of the Chinese Academy of Sciences (XDB26000000), the National Natural Science Foundation of China (41602021), the National Social Science Foundation of China (19BKG009), the Key Research Program of the Institute of Geology \& Geophysics, CAS Grant (No. IGGCAS201905), and SKLLQG grant (No.SKLLQGZR2002). S.X. Yang received the support of the Alexander von Humboldt Foundation, the Youth Innovation Promotion Association of Chinese Academy Sciences (No. 2020074) and the Max Planck Society.

Open Access This article is licensed under a Creative Commons Attribution 4.0 International License, which permits use, sharing, adaptation, distribution and reproduction in any medium or format, as long as you give appropriate credit to the original author(s) and the source, provide a link to the Creative Commons licence, and indicate if changes were made. The images or other third party material in this article are included in the article's Creative Commons licence, unless indicated otherwise in a credit line to the material. If material is not included in the article's Creative Commons licence and your intended use is not permitted by statutory regulation or exceeds the permitted use, you will need to obtain permission directly from the copyright holder. To view a copy of this licence, visit http://creativecommons.org/licenses/by/4.0/.

\section{References}

Adams B, Blades BS (2009) Lithic materials and Paleolithic societies. Blackwell Publishing, New York

Andrefsky W (1994) Raw-material availability and the organization of technology. Am Antiq 59:21-34

Andrefsky W (2009) The analysis of stone tool procurement, production, and maintenance. J Archaeol Res 17:65-103

Binford LR (1979) Organization and formation process: looking at curated technologies. J Anthropol Res 35:255-273

Blades BS (2001) Aurignacian lithic economy: ecological perspectives from southwestern France. Kluwer Academic/Plenum Publishers, New York

Brantingham PJ, Olsen JW, Rech JA, Krivoshapkin AI (2000) Raw material quality and prepared core technologies in Northeast Asia. J Archaeol Sci 27:255-271

Bureau of Geology and Mineral Resources of Heilongjiang Province (1993) Regional geology of Heilongjiang Province. Geological Publishing House, Beijing (in Chinese)

Buvit I, Izuho M, Terry K, Konstantinov MV, Konstantinov AV (2016) Radiocarbon dates, microblades and Late Pleistocene human migrations in the Transbaikal, Russia and the Paleo-Sakhalin-HokkaidoKuril Peninsula. Quat Int 425:100-119

Chen QJ, Jia WM, Doelman T, Zhao HL, Wang CX (2015) A preliminary assessment of obsidian sources using PXRF in the eastern of Jilin Province. In: Institute of Cultural Heritage of Shandong University, East Asia archaeology 12. Science Press, Beijing, pp 442-454 (in Chinese)

Cziesla E (1990) On refitting stone artefacts. In: Cziesla E, Eickhoff S, Arts N, Winter D (eds) The big puzzle: international symposium on refitting stone implements. Holos Press, Bonn, pp 9-44

Daffara S, Borel A, Moncel MH (2019) Conditioning of the raw materials on discoid exploitation strategies during the early middle
Palaeolithic: the example of Payre level D (South-East France). Archaeol Anthropol Sci 11:4681-4695

Dibble HL (1995) Middle Paleolithic scraper reduction: background, clarification, and review of the evidence to date. J Archaeol Method Theory 2:299-368

Dong ZA (1989) Microliths from Dabusu, western Jilin Province. Acta Anthropol Sin 8:49-58 (in Chinese)

Douglass MJ, Holdaway SJ, Fanning PC, Shiner JI (2008) An assessment and archaeological application of cortex measurement in lithic assemblages. Am Antiq 73:513-526

Du SS (2003) A preliminary study on raw material exploitation in Middle-Upper Paleolithic sites in Nihewan basin. Acta Anthropol Sin 22:21-130 (in Chinese)

Ekshtain R, Tryon CA (2019) Lithic raw material acquisition and use by early Homo sapiens at Skhul, Israel. J Hum Evol 127:149-170

Gao X (2001) A study of raw material exploitation and economy at Zhoukoudian locality 15. Acta Anthropol Sin 20:186-200 (in Chinese)

Huang WW, Zhang ZH, Liao ZD, Yu HM, Chu BJ, Gao ZC (1984) Discovery of Paleolithic artifacts at Ang'angxi of Jijihear, Heilongjiang. Acta Anthropol Sin 3:242-250 (in Chinese)

Inizan ML, Reduron-Ballinger M, Roche H, Texier J (1999) Technology and terminology of knapped stone. Cercle de Recherches et d'Etudes Préhistoriques, Nanterre

Izuho M, Ferguson JR, Vasilevski A, Grishchenko V, Yamada S, Oda N, Sato H (2017) Obsidian sourcing analysis by X-ray fluorescence (XRF) for the Neolithic sites of Slavnaya 4 and 5, Sakhalin Islands (Russia). Archaeol Res Asia 12:54-60

Jia PW, Doelman T, Chen C, Zhao H, Lin S, Torrence R, Glascock MD (2010) Moving sources: a preliminary study of volcanic glass artifact distributions in Northeast China using PXRF. J Archaeol Sci 37: $1670-1677$

Kato S (2017) The use of lithic raw materials during the Upper Paleolithic in eastern China: a focus on microblade industries. Quat Int 442:6677

Kelly RL (1992) Mobility/sedentism: concepts, archaeological measures, and effects. Annu Rev Anthropol 21:43-66

Kudo Y, Kumon F (2012) Paleolithic cultures of MIS 3 to MIS 1 in relation to climate changes in the central Japanese islands. Quat Int 248:22-31

Kuhn SL (2004) Upper Paleolithic raw material economies at Üçağızlı cave, Turkey. J Anthropol Archaeol 23:431-448

Kunikita D, Shevkomud I, Yoshida K, Onuki S, Yamahara T, Matsuzaki H (2013) Dating charred remains on pottery and analyzing food habits in the Early Neolithic period in Northeast Asia. Radiocarbon 55:1334-1340

Kunikita D, Wang LX, Onuki S, Sato H, Matsuzaki H (2017) Radiocarbon dating and dietary reconstruction of the early Neolithic Houtaomuga and Shuangta sites in the Song-Nen Plain, north-east China. Quat Int 441:62-68

Kuzmin YV (2014) The Neolithization of Siberia and the Russian Far East: major spatiotemporal trends (the 2013 state-of-the-art). Radiocarbon 56:717-722

Kuzmin YV, Speakman RJ, Glascock MD, Popov VK, Grebennikov AV, Dikova MA, Ptashinsky AV (2008) Obsidian use at the Ushki Lake complex, Kamchatka Peninsula (northeastern Siberia): implications for terminal Pleistocene and early Holocene human migrations in Beringia. J Archaeol Sci 35:2179-2187

Kuzmin YV, Glascock MD, Izuho M (2013) The geochemistry of the major sources of archaeological obsidian on Hokkaido Island (Japan): Shirataki and Oketo. Archaeometry 55:355-369

Li YQ (2012) The preliminary report on the survey and test-excavation of Xiaolongshan Paleolithic site, Tieli, Yichun. North Cult Relics 3:37 (in Chinese)

Li YQ (2015) Findings and dates of the Linfu Paleolithic site, Heilongjiang Province. In: Inner Mongolia museum, Institute of 
Cultural Relics and Archaeology of Inner Mongolia, Ancient cultures of the northern area of China, Mongolia and Baikalian Siberia (I). Science Press, Beijing, pp 121-127 (in Chinese)

Li YQ (2019) A preliminary report on the excavation of Xiaolongtoushan site, Hailin, Heilongjiang Province. Acta Anthropol Sin. https://doi. org/10.16359/j.cnki.cn11-1963/q.2019.0020 (in Chinese)

Li YQ, Chen QJ (2014) Study on the technological patterns in obsidian Paleolithic of Changbai Mountain. Dongbei Shidi 5:3-6 (in Chinese)

Li F, Kuhn SL, Chen F, Gao X (2016) Raw material economies and mobility patterns in the late Paleolithic at Shuidonggou locality 2, North China. J Anthropol Archaeol 43:83-93

Li XQ, Zhao C, Zhou XY (2019) Vegetation pattern of Northeast China during the special periods since the last glacial maximum. Sci China Earth Sci 62:1224-1240

Lin SC, McPherron SP, Dibble HL (2015) Establishing statistical confidence in cortex ratios within and among lithic assemblages: a case study of the Middle Paleolithic of southwestern France. J Archaeol Sci 59:89-109

Liu S, Chen QJ, Cui JF, Wu XH (2014) The provenance of obsidian artifacts from the Upper Paleolithic sites in eastern Jilin Province, China. In: Research Center for Chinese Frontier Archaeology of Jilin University, Research of China's frontier archaeology 16. Science Press, Beijing, pp 261-276 (in Chinese)

Liu W, Li YQ, Yang SX (2019) The trial excavation of the Xishantou site of the Paleolithic age in Longjiang County, Heilongjiang Province. Archaeology 11:3-13 (in Chinese)

Mingram J, Stebich M, Schettler G, Hu Y, Rioual P, Nowaczyk N, Dulski P, You H, Opitz S, Liu Q, Liu J (2018) Millennial-scale East Asian monsoon variability of the Last Glacial deduced from annually laminated sediments from Lake Sihailongwan, N.E. China. Quat Sci Rev 201:57-76

Nelson MC (1991) The study of technological organization. J Archaeol Method Theory 3:57-100

Ono A, Glascock M, Kuzmin IV, Suda Y (2014) Methodological issues for characterisation and provenance studies of obsidian in Northeast Asia. Archaeopress, Oxford

Parry WJ, Kelly RL (1987) Expedient core technology and sedentism. In: Johnson JK, Morrow CA (eds) The organization of core technology. Westview Press, Boulder, pp 285-304

Sato H, Natsuki D (2017) Human behavioral responses to environmental condition and the emergence of the world's oldest pottery in East and Northeast Asia: an overview. Quat Int 441:12-28

Shoda S, Lucquin A, Yanshina O, Kuzmin Y, Shevkomud I, Medvedev V, Derevianko E, Lapshina Z, Craig OE, Jordan P (2020) Late Glacial hunter-gatherer pottery in the Russian Far East: indications of diversity in origins and use. Quat Sci Rev 229:106124

Shott M (1986) Technological organization and settlement mobility: an ethnographic examination. J Anthropol Res 42:15-51

Sisk ML, Shea JJ (2008) Intrasite spatial variation of the Omo Kibish Middle Stone Age assemblages: artifact refitting and distribution patterns. J Hum Evol 55:486-500

Soressi M (2002) Le Moustérien de tradition acheuléenne du sud-ouest de la France. Discussion sur la signification du faciès à partir de l'étude comparée de quatre sites: Pech-de-l'Azé I, Le Moustier, La Rochette et la Grotte XVI. Dissertation, Université Bordeaux I

Soressi M, Geneste JM (2011) The history and efficacy of the chaine opératoire approach to lithic analysis: studying techniques to reveal past societies in an evolutionary perspective. PaleoAnthropology 2011:334-350

Stebich M, Mingram J, Han J, Liu J (2009) Late Pleistocene spread of (cool-) temperate forests in Northeast China and climate changes synchronous with the North Atlantic region. Glob Planet Chang 65:56-70

Wang LX (2018) Studies on the remains of the Neolithic Age in Houtaomuga site and relevant issues. Acta Archaeol Sin 2:141164 (in Chinese)

Wang LX, Sebillaud P (2019) The emergence of early pottery in East Asia: new discoveries and perspectives. J World Prehist 32:73-110

Wang C, Lu HY, Zhang JP, Gu ZY, He KY (2014) Prehistoric demographic fluctuations in China inferred from radiocarbon data and their linkage with climate change over the past 50,000 years. Quat Sci Rev 98:45-59

Wu J, Liu Q (2013) Charcoal-recorded climate changes from Moon Lake in Late Glacial. Chin J Geol 48:860-869 (in Chinese)

Wu J, Shen J (2010) Paleoenvironmental and paleoclimatic changes in Lake Xingkai inferred from stable carbon and nitrogen isotopes of bulk organic matter since $28 \mathrm{kaBP}$. Acta Sedimentol Sin 28:365-372 (in Chinese)

Wu J, Liu Q, Wang L, Chu GQ, Liu JQ (2016) Vegetation and climate change during the Last Deglaciation in the Great Khingan Mountain, northeastern China. PLoS One 11:e0146261

Wynn T, McGrew W (1989) An ape's view of the Oldowan. Man 24: 383-398

Yang SX, Yue JP (2020) The raw material study and its application on explanation of prehistoric habitants' cognitive level and behavioral pattern. Acta Anthropol Sin 39:12-20 (in Chinese)

Yang SX, Zhang YX, Li YQ, Zhao C, Li XQ, Yue JP, Hou YM, Deng CL, Zhu RX, Petraglia MD (2017a) Environmental change and raw material selection strategies at Taoshan: a terminal Late Pleistocene to Holocene site in North-Eastern China. J Quat Sci 32:553-563

Yang SX, Zhang YX, Zhu TQ, Hou YM, Zhou T (2017b) Provenancing hornfels in the Dingcun industry: the exploitation of the vicinity source. Quat Int 434:138-147

Yue JP (2019) Lithic technology and environmental adaptation of prehistoric habitants during the terminal Pleistocene in southern Lesser Khingan Mountains, Northeast China. Dissertation, University of Chinese Academy of Sciences (in Chinese)

Yue JP, Hou YM, Yang SX et al (2017) A preliminary report on the 2014 excavation at Taoshan site in Heilongjiang Province, Northeast China. Acta Anthropol Sin 36:1-13 (in Chinese)

Yue JP, Li YQ, Yang SX (2019) Neolithisation in the southern Lesser Khingan Mountains: lithic technologies and ecological adaptation. Antiquity 93:1144-1160

Yue JP, Yang SX, Hou YM, Potter BA, Li YQ, Chang Y (2020) Late Pleistocene lithic technology and human adaptation in Northeast China: a case study from Taoshan site. Quat Int 535:48-57

Zheng HX, Yan S, Qin ZD, Wang Y, Tan JZ, Li H, Jin L (2011) Major population expansion of East Asians began before Neolithic time: evidence of mtDNA genomes. PLoS One 6:e25835

Zou GN, Shelach G, Li XQ, Zhao C, Rui X, Zhou LP, Zhang JF (2018) Geochronology and paleoenvironment of the Taoshan site, northeastern China, and archaeological implications. Quat Int 463:6-17

Publisher's note Springer Nature remains neutral with regard to jurisdictional claims in published maps and institutional affiliations. 